\title{
Religión y liberación. Perspectivas
}

\author{
Ariel Corpus ${ }^{1}$ \\ Red Mexicana de Estudios sobre el Protestantismo
}

\begin{abstract}
RESUMEN: La Teología de la Liberación plantea hablar sobre Dios y el problema del hombre en situaciones concretas, en aspectos que no concibe relaciones fuera del hombre en su historia, su filosofía, su ética y su economía. Esta aportación puede ayudar a repensar la religión desde espacios que busquen la liberación por la dignidad bumana, en contra de los totalitarismos y del dogmatismo, aquello que usurpa la imagen de Dios.
\end{abstract}

\begin{abstract}
Theology of liberation speaks about God and buman problem in concrete situations, in aspects that do not conceive relations away from the buman beings on their history, their philosophy, their ethics and their economy. This contribution may help to rethink religion from spaces that look for liberation for buman dignity, against totalitarianism and dogmatism, which usurps God's image.
\end{abstract}

\section{A Meli con cariño, mi abuelita...}

En la actualidad existen cientos y cientos de personas que viven en condiciones de miseria. Tan sólo en México se calcula que cerca del 40\% vive en pobreza extrema, mientras que la población dueña de los medios de producción no rebasa la décima parte. Aquellos que, mediante sus políticas, se denominan como los "elegidos", justifican la exclusión de millones de personas reduciéndolos al papel de "objetos de consumo". Sin embargo, los movimientos a favor de la dignidad humana, la naturaleza y la cultura han estado presentes, al igual que los movimientos que resisten desde las armas como único medio, puesto que la "legalidad" ha quedado desacreditada, han estado presentes en los últimos años. Con 
el movimiento zapatista en la zona de Chiapas, vientos esperanzadores dejaron una brisa por construir un mundo mejor.

Sin embargo, la lucha, si así queremos llamarla, no se limita a espacios seculares, pues también desde la trinchera una oleada de intelectuales religiosos demanda un mundo más justo bajo nuevas hermenéuticas de sus tradiciones religiosas, de tal modo que sea visible un Dios que defienda la vida, un Dios que niegue la necesidad de sacrificios puesto que en su personalidad no cabe ese método. Desde pequeños espacios, se han constituido movimientos eclesiásticos que rechazan al Dios neoliberal que mediante sus políticas genera día a día millones de pobres y peor aún, lo valida.

El retorno a lo sagrado, si es que este concepto es válido, rompió la propuesta de secularidad. Con esto, el proceso de modernidad se ha puesto en crisis, ya que no ha podido ocupar el pedestal en la conciencia de los individuos y de las clases sociales. Tal pareciera que la modernidad ha ayudado en la búsqueda de los diversos sectores a participar en núcleos de liberación ante un mundo que se consume a sus ojos. En este retorno a lo sagrado, creyentes, creyentes a medias y quienes no lo son, han corrido a las religiones a socorrerse, puesto que les otorga un sentido de vida, una apuesta de fe.

A finales de la década de los sesenta surgen movimientos sociales que pregonaban el rompimiento de la estructura de la sociedad occidental, entiéndase esto como la lógica del capitalismo con todas sus irracionalidades como lo diría Franz Hinkelamert. Ante esto, no sólo las personas que simpatizaban con el socialismo, y que se declaraban como no creyentes en una deidad, participaron en procesos de lucha que intentaron romper esta lógica del mercado mundial y que impregnaba los aspectos de la vida social, sino también un movimiento de corte religioso denominado como Teología de la Liberación. Ella, o mejor dicho, sus simpatizantes, creyentes y no creyentes, no sólo usaron la referencia del marxismo para abordar metodológicamente la acción de Dios en la historia, sino que pregonaron en rompimiento con otras formas y maneras del quehacer teológico en el momento.

De este modo, la Teología de la Liberación plantea hablar sobre Dios y el problema del hombre en situaciones concretas, en aspectos que no concibe relaciones fuera de la misma vida concreta de los actores terrenales, el hombre en su historia, su filosofía, su ética y su economía. 
Esta aportación puede ayudar a repensar la religión desde espacios que busquen la liberación por la dignidad humana, en contra de los totalitarismos y del dogmatismo, aquello que usurpa la imagen de Dios. Trabajar la religión desde una propuesta ética de liberación humana, deconstruyendo a ese Dios cultural y proponiendo al hombre como la plenitud de Dios; deconstruyendo a ese Dios masculino occidental y enfocando la feminidad de Dios; deconstruyendo a ese Dios triunfador y dando lugar a un Dios que opta por los derrotados y empobrecidos; deconstruyendo a ese Dios que obliga a morir por la ley y mostrando a ese Dios que propone una economía con ética, en resumen, trabajando con las imágenes de Dios.

\section{Sujeto e indagación ética}

Un aporte de la Teología de la Liberación (TL) y que representa la fundamentación ética de ésta, es la recuperación de la categoría de sujeto. Como mencionamos anteriormente, la TL se concretiza en el quehacer humano, puesto que pone en crisis aquellas teologías que no hablan sobre los desfavorecidos y que solo atienden y respaldan a los "elegidos", en frases de Gustavo Gutiérrez diríamos que no implican una reflexión crítica. Este postulado puede basarse en el principio bíblico: "amarás a tu hermano como a ti mismo", puesto que la indagación ética significa ver al "otro" como igual. El "otro" es aquel que no soy yo para la lógica capitalista, puesto que no tiene la capacidad de convertirse en un consumidor. Sin embargo, también puede significar "yo". "Yo" no soy, si el "otro" no es, es decir, mi plenitud como persona se circunscribe a la plenitud del "otro". Para la TL son los históricamente marginados y empobrecidos aquellas personas que se les tiene que ver como sujetos, y no como objetos-consumo, como lo pretender ver la lógica capitalista. Sin embargo, para que nazca esta indagación al interior, tiene que existir el reconocimiento del "otro" como humano, lo cual implica el rompimiento de la lógica del mercado donde en ella se obtiene el carácter de humano en la medida de su potencial de consumo: ${ }^{2}$

En una cultura de consumo, el patrón de consumo es el factor determinante en la definición de la identidad y el reconocimiento de los individuos. Los no-consumidores son vistos como no-personas cuanto más bajo el lugar que ocupan en la jerarquía socio-cultural, menos humanos. 
En la indagación ética, en cambio, la humanidad de las personas es reconocida mas allá de su papel o lugar social. Las personas son reconocidas en la gratuidad, vale decir, con independencia de su capacidad de consumo, condición social, sexual, étnica, religiosa, etc. ${ }^{3}$

El reconocimiento de aquel que denominamos como "otro" se vuelve para la TL, mediante su análisis ético, la puerta de entrada en la conformación de sujetos actores y actuantes en la historia:

[...] este reconocimiento gratuito entre sujetos en la relación sujeto-sujeto, 'cara a cara', es una verdadera experiencia espiritual de la gracia y de la justificación por la fe. Es una experiencia que justifica la existencia, no sólo de la persona oprimida, sino igualmente la de quien siente la indagación. Razón por la cual tal experiencia es percibida como libertadora tanto para quien siente la indagación, como para la victima que es reconocida como persona. ${ }^{4}$

De la "indagación”, que implica el reconocimiento del otro como igual, podemos pasar a reflexionar acerca del sujeto, es decir, ¿quién es o qué es el sujeto? La categoría de sujeto nace de la tradición judeocristiana e implica la soberanía de Dios como sujeto de la historia. Sin embargo con el proceso de modernidad y secularización el Dios-sujeto es suplantado por el Hombre-sujeto:

La modernidad usurpa de Dios la imagen de sujeto y la transfiere al ser humano. [...] Al entrar en la modernidad, la religión explota, pero sus componentes no desaparecen. El sujeto cesando de ser divino o ser definido como la Razón, se torna bumano, personal, se torna una cierta relación del individuo o del grupo con ellos mismos, y que el sujeto de la modernidad no es otro que el descendiente secularizado del sujeto de la religión. ${ }^{5}$

Y se vincula directamente con la actuación en la historia y la toma de decisiones que transformen el mundo concreto en lo religioso, político, social, económico, etc.

En la construcción del concepto de sujeto de la historia ocurre, simultáneamente, la construcción del concepto de historia como objeto a ser construido por el sujeto-humano. [...] No obstante, durante la mayor parte del tiempo la historia humana fue percibida como definida por los dioses o por la Razón. Con la modernidad surge esta novedad: 
la percepción de la historia como siendo construida por sujetos humanos. ${ }^{6}$

Precisamente los constructores de la historia, como sujetos-humanos que propone la reflexión de la TL son aquellos excluidos por la lógica del sistema económico mundial, que intenta reducirlos a un papel de consumidores. Sin embargo, la lógica de este sistema también propuso de algún modo dicho concepto de sujeto. Empero, en su interpretación, este se rige por la "ley" con la finalidad de avanzar a la construcción de un horizonte utópico, es decir, la construcción de un mundo donde no exista pobreza y exclusión:

En la construcción de la historia por el sujeto-humano moderno, la razón desempeña un papel central. El individuo se convierte en sujeto en la medida que crea un mundo regido por leyes racionales e inteligibles para el pensamiento humano. $\mathrm{Y}$ esa creación de un mundo racional es vista como la realización del progreso que nos llevaría al 'jardín de Edén'. El Dios-ordenador de mundo y de la historia es remplazado por el sujeto-humano ordenador del mundo y de la historia conforme a la razón.

Ante esta manera de pensar surge la critica de Hinkelammert y Assman, pues se pensaba que los modelos económicos (capitalismo y socialismo) y el cristianismo (como la búsqueda por construir el Reino de Dios) serían capaces de llevar a una plenitud sincera para los individuos, el camino hacia la utopía; un mundo más justo, equitativo y solidario:

Creer que es posible con acciones humanas finitas construir un mundo pleno que presupone conocimiento, tiempo y espacios infinitos. Ilusión esta que forma parte del meollo de los proyectos de mercado perfecto del neoliberalismo, de la planificación perfecta del socialismo de modelo soviético y hasta de muchos proyectos de 'construcción de Reino de Dios'. El problema de esta ilusión no se reduce al campo teórico; ella engendra sistemas sacrificiales, sistemas e instituciones sociales que exigen sacrificios de vidas humanas como 'costo necesario' para alcanzar el 'paraíso', la 'redención' de la historia y la humanidad. ${ }^{8}$

Por tal razón, la reformulación en el concepto de sujeto es una reflexión dentro de la TL, debido a que hace referencia a los excluidos; a los negros puesto que el mundo se piensa desde lo blanco; a las mujeres, puesto que está presente lo masculino en el imaginario; a los jóvenes 
y niños pues la sociedad concibe la plenitud desde lo adulto; y desde luego los empobrecidos quienes serán los nuevos sujetos-humanos ordenadores de la historia en busca de la utopía.

Ahora bien, la indagación ética no nace por causa de la conciencia de la no-realización del 'destino' o del orden preestablecido. La indagación ética [...] nace del reconocimiento de la humanidad de la persona que está siendo negada en la relación y/o en el sistema social. Es de la experiencia del 'cara a cara' que brota la contestación a las injusticias y los males del mundo, una indagación surgida de alguna teoría, sin esta experiencia fundacional del 'cara a cara', no dura mucho, cae en el olvido o desaparece en medio de alguna realización pragmática. ${ }^{9}$

Por tal motivo, el círculo hermenéutico de la TL, la teología (como reflexión bíblica de juicio) es acto segundo, mientras que lo primordial, pues de ahí nace la indagación ética y el reconocimiento del otro como humano-sujeto, es la praxis. El teólogo católico Pablo Richard nos explica que el sujeto-humano se reconoce necesariamente en la relación con el "otro" o los "otros". Y a diferencia del sujeto-individual propuesto por la lógica del mercado, propone el sujeto-comunidad:

Debemos distinguir la concepción individualista del sujeto que afirma su identidad en un yo solitario, de la concepción comunitaria del sujeto que afirma su identidad en un nosotros, en una comunidad [...] El sujeto-individuo se afirma en competencia con el otro, en la derrota y eliminación del otro. Es el yo que triunfa en la competencia del mercado y en la acumulación personal del capital. El otro solo existe si me reconoce a mi o me es útil. El sujeto-comunidad, por el contrario, busca al otro como condición de su propia existencia como sujeto. ${ }^{10}$

En este sentido el sujeto se piensa a partir de la existencia del otro, y es entonces donde cobra sentido la propia existencia de sujeto, lo que hablamos al principio, la indagación ética y el reconocimiento mutuo. En ambos ejemplos de sujetos y en parámetros económicos diría: "El sujetoindividuo dice: 'si no hay para todos, que por lo menos haya para mí'. Mientras el sujeto-comunidad dice: 'si hay para todos, entonces hay para mí’"11. Este sujeto-comunidad es quien será capaz de repensar nuevos horizontes y será quien, en sentido comunidad, ayude a construirlos: 
El sujeto-comunidad, capaz de construir un mundo alternativo, valoriza hoy más que nunca la dimensión ética del desarrollo económico, social y político. Un cambio de sistema no puede darse sin una opción ética y radical por la vida humana y cósmica como valor absoluto. ${ }^{12}$

De la indagación ética se construye el término categórico de sujeto, el cual abordaremos más adelante. No obstante, otro punto importante en la propuesta de religión y liberación se encuentra el carácter de la negación del sacrificio, donde se escucha el clamor y el grito de los negados y marginados de la historia, y de los cuales la TL hace escuchar su voz. Para hacer el juicio de valor de victimas y victimarios, es menester una reflexión acerca del discurso religioso y su interpretación en el mundo de carne y hueso, en el mundo de las disciplinas y, en este caso, de la economía. Puesto que el sujeto se construye basándose en la exclusión, ¿de donde surgen esas víctimas?

\section{Teología y economía; la defensa por la vida}

Para Hinkelammert, la relación entre estas dos disciplinas (la teología y la economía) se da en un plano bíblico, pues representa un método de justificación ante la situación y su propuesta de sacrificialidad en búsqueda de los mundos perfectos. Ante esto, con ayuda de nuevas exégesis plantea un discurso diferente al que comúnmente se ha interpretado del texto bíblico ${ }^{13}$. El texto del Padre Nuestro brinda un punto de partida en la reflexión, debido a que un evangelio dice: "Perdónanos nuestras deudas, como también nosotros hemos perdonado a nuestros deudores", ${ }^{14}$ mientras que otro: "Perdónanos nuestros pecados, porque también nosotros perdonamos a todos los que nos ofenden"15. Ante esto, hay que considerar el cambio en el significado de pecado y deuda, pues para Lucas la forma en que Jesús oró se refirió en un plano "espiritual” del cual Dios sólo puede perdonar pecados. Sin embargo para Mateo (quien además podemos decir que era un conocedor de la economía) la forma de orar fue en relación a deuda, lo cual es justo en las normas del mercado, ante esto:

[...] en el Padre Nuestro el ser humano no ofrece a Dios pagar las deudas que tiene con Él, ni las deudas que a contraído con otros seres humanos. Al contrario, le pide a Dios que le perdone las deudas sin pagarlas, y a cambio le ofrece perdonar también las deudas que otros seres humanos tienen con él, sin que se las paguen. ${ }^{16}$ 
Hinkelammert agrega que no se trata de cualquier deuda, puesto que en los tiempos en que fue escrito el Padre Nuestro, la deuda a la cual se refería era prácticamente impagable ${ }^{17}$. Es importante esto, puesto que la deudas en un plano legal son justas, mientras que los pecados y las ofensas entran dentro del orden moral y la conciencia privada, no así la deudas que se justifican mediante reglas jurídicamente establecidas. Al estudiar y prestar atención a este texto, hace alusión a la teología de Anselmo de Canterbury en el siglo XI, ante el cual, el humano no tiene con que pagar la deuda impagable:

[...] Anselmo concibe la justicia de Dios en contradicción con el perdón de la deuda. Perdonar la deuda sería una falta de justicia de Dios. El Dios de Anselmo no puede perdonar la deuda, y no la perdona. El exige el pago, y la justicia es cobrar la deuda, aunque sea impagable. En consecuencia, si el ser humano no la paga, toda la eternidad sufrirá en el infierno el hecho de que la tiene que pagar. ${ }^{18}$

Concebido así, la deuda por más dura y difícil que signifique costearla tiene que ser pagada, ante lo cual Dios exige un sacrificio con esta finalidad. El Dios de Anselmo en lugar de perdonar la deuda, exige el pago de ella. Anselmo nos muestra un Dios que no perdona por gracia, sino por dolor de un victimario, en este caso su Hijo al cual entrego por considerarse incapaz de perdonar sin sufrimiento:

En vez de perdonar la deuda, Dios sacrifica a su Hijo para que su sangre sirva como medio de pago del ser humano, de modo que éste pueda cumplir con su obligación de pagar la deuda. Por ende, el ser humano paga con la sangre de Cristo, y así la justicia está salvada. ${ }^{19}$

De este modo, la visión de Anselmo es presentar un Dios legalista, que justifica la muerte con la finalidad del pago de una deuda, pues no existiendo otra salida recurre a este método. Aquí insertamos la critica al modelo neoliberal que justifica los sacrificios en pos de alcanzar el horizonte utópico, en pos de una sociedad donde no exista pobres, donde todos tengan capacidad de consumo, la justicia es pagar la deuda, en este caso la gracia no es válida, solo el sufrimiento en pos de alcanzar el fin:

Con Anselmo aparece un tipo de justicia que ya no tiene nada que ver con la justicia de la Biblia. Es una justicia del pago de lo que se debe, una justicia del cumplimiento de normas, una justicia 
que mata a su propio hijo para lograr el cobro de las deudas y el cumplimiento de las normas. Aparece un Dios horrendo, al cual el pobre ya no puede recurrir. Es un Dios que habla el lenguaje del Fondo Monetario Internacional (FMI).

[...] una vez arraigada en el corazón de la religiosidad, esta relación económica baja a la tierra y transforma la Edad Media en una época de tránsito hacia la sociedad burguesa. Este corazón de la religiosidad es ahora el cumplimiento de contratos como principio de toda justicia. ${ }^{20}$

Lo cual se cumple en el devenir de la sociedad, debido a que la economía de mercado necesita estas víctimas de la historia ya que: “[...] al avanzar hacia el paraíso prometido tiene que producir esas víctimas, cuya suerte no cuenta de cara el gran final hacia el cual se avanza" ${ }^{21}$, es decir que "la historia vive de sacrificios humanos"22:

La víctima es el pobre, pero visto frente a una ley de la historia que comete en él un sacrificio humano en un altar erigido en nombre de esta ley. Lo que se revela en la ley de la historia es un Dios sacrificador, en nombre de cual se devora a los seres humanos y, al final, a la tierra misma. Hoy esta ley de la historia se hace presente en el pago de la deuda externa del Tercer Mundo, sacrificando a su paso por la historia a los pueblos y a la naturaleza. ${ }^{23}$

Sin embargo, si preguntamos a algunas propuestas religiosas, el pago de una deuda sería correcto siempre y cuando exista el cumplimiento de esta. No así el pago de esta deuda, donde Dios se muestra como arrogante victimario que necesita ardientemente cobrar este pago mediante la sangre de alguien. Él no puede omitir el cobro, se siente incapaz. Anselmo lo hace incapaz por la gracia, por tal motivo acude al sacrificio:

Para muchos, es cristiano pagar la deuda, aunque todo sea sacrificado. Una larga tradición sacrificial se a apoderado del cristianismo, sobre todo a partir de la teología de Anselmo de Canterbury, cuya esencia es: el ser humano es sacrificado, y con Cristo acepta ser sacrificado. Su perfección reside en aceptar que haya victimas [...] Se trata de la imagen de un Dios que no puede perdonar a la humanidad la deuda que tiene con el, por cuanto su justicia exige el cumplimiento de la ley, aunque eso signifique sacrificar a su propio Hijo. Y en pos del cumplimiento de la ley, sacrifica a su Hijo. $^{24}$ 
Esta concepción de Dios que exige el pago de la deuda mediante el sacrificio implica la lógica de aquellos sistemas que niegan otras posibilidades, aunque no sea el perdón de la deuda, y que se tornan como autoritarios y pregonan ser la única solución. Ante esto, el sistema crítico de la TL impone un cuestionamiento y se rebela contra el Dios de Anselmo, de tal modo que opta por la 'vida' antes de la muerte por un 'modo de vida', esto implica estar del lado de aquellas víctimas de la historia y "cuestionar esa tradición sacrifical de la fe cristiana." 25

La analogía de Abraham en el texto bíblico permite entender esto. Al patriarca, Dios le da una ordenanza que radica en disponer la vida de su hijo Isaac para probar la fe del primero, si lo mata probará tener fe, sin embargo:

En vez de sacrificarlo, lo salvo para Dios. Y este orgullo de ponerse por encima de la ley y ajustarla a la vida del ser humano, Dios lo reconoce como fe y lo recompensa con la renovación de la promesa. ${ }^{26}$

Lo cual es una rebelión ante la ley de Dios, o de un Dios que exigía el sacrificio. La "ley" ordenaba tajantemente la vida de la victima, ante lo cual, Abraham no podía negarse puesto que por la ley de Dios se pidió la vida de su hijo. Sin embargo en este trance surge otra ley en la conciencia de Abraham, la ley de la vida por lo tanto se negó a cumplir la voluntad de Dios que le pedía la vida en sacrificio, apostó por una fe:

En esta su forma más fiel, el mito de Abraham es un grito de libertad, una afirmación del ser humano frente a la ley que mata; es la exigencia de someter la ley a las necesidades de la vida humana. De esa forma se devuelve a Abraham lo que hace su grandeza. Pero se devuelve su grandeza también a Dios, quien no es el Dios de los sumisos, sino el Dios del ser humano que se hace señor de su propia historia. También el Dios de aquellos que se levantan contra las leyes metafísicas de la historia, en nombre de las cuales se sacrifica a los seres humanos. ${ }^{27}$

Los actores vetero-testamentarios son reflejo de aquella indagación ética y la construcción de sujetos que se reconocen mutuamente como tal, dando paso a una hermandad que reivindica su derecho de ser sujetos y por lo tanto constructores de su historia: 
Abraham es el victimario potencial que se convierte y deja de serlo. Isaac es la victima potencial, cuya resistencia logra la conversión de su padre a la libertad. Abraham se hace libre al dejar libre a su hijo. La libertad la consiguen los dos en su encuentro, que es un encuentro de hermanos. [...] Aquel dios que lo mandaba sacrificar a Isaac resulta un dios falso. ${ }^{28}$

También es necesario afirmar que la conciencia de Abraham por la vida fue importante para descubrir ese Dios que niega la necesidad del sacrificio de la victima. Abraham escuchó la voz de Dios que desde el cielo le gritaba un alto a la muerte venidera, que a la vez, fue la voz de su conciencia reconociendo al otro como igual y sin necesidad de hacerlo victima $^{29}$, por lo tanto pudo discernir entre el Dios que opta por la vida y aquel quien exige el sacrificio como paga. En palabras de Hinkelammert:

Se necesita fe para poder reivindicar la libertad. Hoy, todo un mundo está amenazado de ser sacrificado en nombre de la ley de la historia, que se formula como ley del mercado. Se necesita afirmar la libertad para imponerse a esta ley y asegurar la vida humana, para que ella no sea sacrificada. Hoy todo el mundo es Isaac, no obstante el victimario no se quiere reconocer como Abraham: ser humano libre que rechazó sacrificar a su hijo por tener fe, y con el cual Dios estableció la alianza sobre la base de esta fe. ${ }^{30}$

Esta es la crítica a la ley de un dios que manda matar por el cumplimiento irreversible de esta. Sin embargo, esta ley que parece justa, por su irremediable cumplimiento, se convierte en una ley que es pecado. Entonces Dios 'peca' al exigir la muerte por el cumplimiento de su ordenanza:

El pecado que se comete en el cumplimiento de la ley, consiste por consiguiente en la destrucción del sujeto viviente en cualquiera de sus formas [...] En términos legalistas, la ley destruye al ser humano cuando elimina la vida como la fuente del discernimiento y de la reflexividad de la ley. ${ }^{31}$

La injusticia del pago por la ley, radica en que la deuda obliga irremediablemente a pagar, por lo tanto se convierte en una ley de muerte, una ley que excluye, una ley que no toma como principio ético y humanitario la vida humana dignificada, una ley que destruye para intentar construir: 
La injusticia se compete cumpliendo la ley, aunque ella sea una ley justa. No se trata por eso, principalmente, de la cuestión de si la ley es justa o no. Eso se refiere a un plano por completo diferente. También la ley justa, al ser cumplida en forma legalista, produce la injusticia [...] Que la ley sea ley de Dios no cambia la situación. También la ley de Dios produce la injusticia si es tratada como ley de cumplimiento, la ley destruye al sujeto viviente, y por eso su cumplimiento legalista, es una ley que mata. ${ }^{32}$

La conciencia-fe de Abraham pudo discernirla la ley que produce injusticia y muerte, y optó por la vida antes de cumplir la ley en forma legalista y matar por ella. Ante lo cual: "La rebelión del sujeto viviente transforma la ley en cuanto le impone su discernimiento a la luz de la vida humana. La interpela, la discierne", ${ }^{33}$ puesto que la ley por sí sola destruye y mata por su cumplimiento:

En el curso de su cumplimiento formal, la ley mata. El pago de la deuda del deudor que no puede pagar, lo mata. En el tiempo de Jesús, el deudor que no podía pagar perdía todos sus bienes, y él y su familia eran vendidos en esclavitud. La ley del pago de la deuda lo mataba por su cumplimiento. Por supuesto, esta matanza no era ninguna trasgresión de la ley. Era el producto para su cumplimiento. ${ }^{34}$

De esta manera se justifica la muerte de millones de seres humanos que no resisten y que mueren a causa del cumplimiento de la ley arraigada en el espíritu de la tradición judeo-cristiana, y que baja del cielo al mundo concreto, por lo cual: "Hoy pueblos enteros son condenados al hambre por tener una deuda impagable, la que se les cobra con sangre y fuego. La ley mata, no obstante, no hay transgresión de una ley". ${ }^{35}$

\section{La religión como constructora de utopías}

Si bien consideramos que la utilización y manipulación de los textos bíblicos justifican, mediante el Dios victimario, las políticas que generan pobreza y destrucción, también enfatizamos que las religiones, como portavoces cada una de sus propios textos sagrados, pueden aportar elementos que nos sirvan para optar por la vida y que mediante nuevas hermenéuticas denuncien los abusos y pregonen la dignidad humana como el pináculo desde donde se emitan juicios de valor. Todo esto, 
sin importar la religión desde donde escriban, pues ante esta situación la lucha común es a favor de valores como la justicia, la paz y la dignidad, ante lo cual el diálogo ecuménico e interreligioso se vuelve sumamente necesario.

Haciendo un poco de historia, recordemos que para los pensadores de finales del siglo XIX y la primera mitad del siglo XX, uno de los debates que implicaba la modernidad era la secularización de la cultura. Ante esta paradoja de concebir al mundo secularizado, la modernidad proponía la desaparición de las religiones por su nula significancia en un mundo ya mayoritario de edad. Inclusive algunos teólogos del lado protestante se "radicalizaron", tomando posturas críticas acerca de su labor, gente como Tillich, Bultmann y Bonhoeffer marcaron una nueva manera de hacer teología a la luz de la crítica. ${ }^{36}$

En nuestro contexto actual, habrá que preguntar si este paradigma es válido aún en esta etapa de "postmodernidad". ¿Es valido seguir usar este término? Es decir, si las religiones están dejando de contribuir a ser una alternativa por un mundo más humano. El capitalismo con su principal política económica de neoliberalismo, como lo hemos visto, a generado las desesperanzas por recuperar un sentido de humanidad, la intolerancia, la degradación del hombre, el abuso del poder y la riqueza de unos cuantos a costa de muchos otros hace que se busquen diferentes alternativas para llevar este mundo hacia un rubro más esperanzador, a la construcción de un mundo más digno.

La pregunta central que podemos plantar con los visto anteriormente, es ¿en qué sirven las religiones hoy en día?, puesto que como hemos visto, principalmente la religión judeocristiana de Occidente, ha justificado el uso de los textos bíblicos con la finalidad de justificar una política de fe, fe en la utopía a costa de las víctimas. Recordemos que con el auge del positivismo en el siglo XIX, la religión era considerada como:

[...] un obstáculo para la emancipación intelectual humana (las ciencias) en función de la racionalidad nueva, o como un factor de atraso para la emancipación social, por ser factor de integración de un orden burgués o servir como base de protesta ilusoria por que está limitada a preocupaciones poshistóricas y, finalmente, como un freno para la emancipación psicológica. ${ }^{37}$

Es decir, las religiones serían incapaces de responder a las necesidades 
del mundo moderno. A pesar de ésta crítica, para François Houtart las religiones han contribuido criticando a la modernidad, aunque muchas veces con una actitud conservadora. Sin embargo, las posturas del mundo occidental no han cambiado, es decir, se sigue viendo "un universo secularizado como realidad fundamental del mundo moderno; o sea, la marginalización de la religión" ${ }^{38}$. De la misma manera, la llamada postmodernidad ha visto a la sociedad y a la religión como algo que declina constantemente y que, cual ebrio, no tiene equilibrio, puesto que se trata solamente de cuentos y creencias vanas. ${ }^{39}$

Sin embargo la llamada racionalidad de un mundo secular y capaz de desechar cualquier superstición religiosa, se pone en crisis a partir de la primera y segunda guerras mundiales, y la guerra fría ${ }^{40}$, lo cual trajo la reivindicación de las religiones y la dinamización de otras, por ejemplo, los pentecostalismos en América Latina, las religiones afroamericanas en las islas del Caribe, el retorno a las religiones prehispánicas y las religiones orientales (islamismo, budismo, etc.) que están cobrando fuerza en el mundo occidental, generando todo un campo abierto de opciones religiosas y reivindicaciones a partir de movimientos ecuménicos e Interreligiosos que intentan generar utopías necesarias para la realización de un mundo más humano. En este sentido los individuos están resistiendo mediante la adhesión a un grupo religioso y se conciben como sujetos de decisión.

Asimismo las investigaciones de corte social han mostrado la importancia de las religiones en movimientos revolucionarios emanados de un verdadero compromiso debido a la similitud de su discurso, como ejemplo, las revoluciones de Nicaragua, El Salvador ${ }^{41}$ y México. En este último país, el zapatismo encontró en los catequistas de la diócesis de San Cristóbal a los futuros líderes de su movimiento. Junto con esto, el ecumenismo nos habla del papel que están tomando las religiones e Iglesias en su forma institucional, donde desde espacios eclesiásticos actúan en contra de la lógica del mercado ${ }^{42}$. De igual modo, los nuevos movimientos interreligiosos. ${ }^{43}$ Estos movimientos han encontrado como su principal contrincante a los grupos conservadores quien defienden la idea de un Dios jerárquico e intolerante, quienes también hacen una interpretación del discurso bíblico, pero desde una perspectiva dogmática negando otras posibilidades de interpretación causando retrocesos en políticas sociales.

Por eso, para Houtart, las religiones con perspectiva liberadora pueden generar aportes que permitan generar una sociedad más humana, 
primero como reconstructoras de la totalidad del universo; segundo como una fuerza simbólica, expresión de la espiritualidad; y tercero como agentes en busca de justicia. En el primer caso, se entiende una simbiosis entre la humanidad y la naturaleza, donde la humanidad es vista como parte de la creación, o se encuentra puesta sobre ella con la finalidad de administrarla. Con esto nos abre la visión de una ética ecológica que se enfrente a las políticas ambientales de contaminación, deforestación y privatización de los recursos naturales. En un segundo momento, no por ello resto de importancia, totalidad implica la unidad solidaria de todo el género humano:

[...] con sus consecuencias concretas en un individuo valorizado por su pertenencia social, en los géneros establecidos según un estatuto de igualdad material y cultural, y en la economía reintegrada como función de la comunidad y no como institución desvinculada del conjunto social, que imponiendo las leyes del mercado a toda vida colectiva de la humanidad. ${ }^{44}$

La reintegración del hombre como un individuo diferente y en algunos casos contradictorio, pero complementario a la vez. La funcionalidad de la sociedad de una manera comunitaria podrá dar una aportación muy importante. En el caso de la unidad respecto a la naturaleza, Houtart menciona:

El precepto bíblico de dominar la tierra fue interpretado de diferentes manera, y frente a la irracionalidad del uso contemporáneo de los recursos naturales, esta perspectiva ha sido reinterpretada. La creación es vista ahora como un conjunto, y la humanidad como parte integral de la naturaleza. ${ }^{45}$

El segundo que comenta se refiera a la fuerza del símbolo como expresión de la espiritualidad, donde para Houtart implica que la espiritualidad no es la virtuosidad como lo entendía Weber, sino que es "sinónimo de vida, de sentido global de la existencia con compromiso, con praxis" ${ }^{46}$ así la espiritualidad es sentido, reflexión y práctica. El símbolo es entendido como un código con el cual "a través de la meditación del mito, del cuento, de la parábola, de la metáfora, del rito, de la fiesta, invita a la praxis". ${ }^{47} \mathrm{El}$ símbolo es entendido como el mensaje profundo más allá de la noción general de la idea, así:

[...] el sabbat en el judaísmo [...] se trasforma en una imposición legalista cuando en realidad se refiere a una liberación 
profunda de los seres humanos. Recordemos la noción de Dios en el Corán explicada por Yusef Seddik, quien subraya su dimensión maternal, opuesta a la representación de Dios como un señor que exige hasta la muerte a sus fieles. [...] Veamos al pan y al vino consagrados, presentados por la institución como fruto de la transustanciación, noción filosófica complicada que implica la presencia real del cuerpo y de la sangre de Jesucristo, cuando el pan y el vino llevan en si mismos un himno a la vida, vida material y espiritual, vida terrena y eterna, vida contra la muerte y contra todo lo que en el mundo contemporáneo se presenta como mortífero $[\ldots]{ }^{48}$

Redefinir el símbolo de la expresión concreta de las religiones es necesario para la construcción de alternativas y será el papel de las religiones que busquen ser fomentadoras de procesos de liberación, debido a que:

No se trata del desarrollo de ideas abstractas o de la construcción de una mitología modernizada. La utopía no se puede pensar sin sus bases materiales, y en este sentido el Evangelio es muy materialista. No puede significar, por ende, la presentación de una espiritualidad desligada de lo real. Pero el mismo tiempo, no puede ser una definición puramente política de la utopía. La vinculación entre la historia y lo posthistórico pertenece a la tarea de las religiones. ${ }^{49}$

El tercer punto que menciona Houtart es conjugar las prácticas religiosas y sociales de liberación y encaminarlas hacia una sola búsqueda de justicia. El propone que las religiones pueden significar mucho en la medida que contribuyan socialmente a favor de los desposeídos:

La humanidad del siglo XXI no podrá reconciliarse consigo misma son revindicar la justicia, y las religiones solamente tendrán un papel humanista si contribuyeran al restablecimiento del sentido de los símbolos, de la mística y de la praxis para crear las referencias y las motivaciones que ayuden a encontrar la trascendencia en el combate de los pobres por la vida. Ellos, los pobres, no necesitan ni de teología, ni de instituciones religiosas para descubrirlo. Mas bien la teología y las instituciones necesitan de los pobres para descubrirla. ${ }^{50}$

Como ejemplo de esto, nos encontramos a las teologías de la liberación en América Latina y en algunos grupos islámicos ${ }^{51}$, y en donde las 
condiciones así lo ameriten para la búsqueda de igualdad y liberación. Así también "las iniciativas o movimientos que se inscriben en esta perspectiva quieren dar una respuesta inmediata a situaciones de destrucción social y corresponde a necesidades reales." ${ }^{2}$

Los tres ejemplos que propone Houtart plantean la integración de la religión como negociantes en un diálogo que permita generar nuevas alternativas al mercado global que el capitalismo a generado con sus desastrosas consecuencias. La liberación de las religiones permite forjar una ética de solidaridad con el individuo, con la comunidad, con el excluido y con el ambiente. Donde éstas no pregonen la "verdad", sino que trabajen solidariamente en busca de la dignidad humana como fin primordial de sus credos, y que más allá de sus dogmas, redefinan el símbolo mediante una espiritualidad basada en valores trascendentes como la justicia, la paz y la igualdad. Para esto, hay que construir desde las propias tradiciones eclesiásticas los elementos necesarios, con ello las Iglesias serán espacios alternativos y liberadores de diálogo y comunión.

\section{Conclusión: espacios eclesiásticos como alternativos y liberadores}

Lo dicho anteriormente es importante, puesto que ahora podemos terminar planteando al sujeto-religioso, o al creyente, como un actor de cambios sociales, precisamente por militar en una institución eclesiástica que le permita constituirse en una comunidad, y de ese modo vivir su sujeticidad resistiendo la lógica que lo pretende objetivar, ya que:

$\mathrm{El}$ individuo no puede vivir sin instituciones y papeles sociales, pero el sujeto no es la suma de tales papeles, mucho menos se identifica con un único papel. Instituciones totalitarias, opresivas, tratan de negar la sujeticidad (la calidad de ser sujeto) del individuo reduciéndolo a un papel social o a un conjunto de papeles, objetivándolo dentro del sistema. ${ }^{53}$

Esto significa que:

Cuando el sistema de mercado capitalista dice a una persona excluida del mercado que ella no tiene derecho a comer y por lo tanto a vivir, por cuanto no es consumidora (carece de dinero para vivir el papel de consumidora), acontece la negación de la sujeticidad de esa persona y su reducción a un papel económico. ${ }^{54}$ 
El reclamo de la Teología de la Liberación, es en contra de lo que niega esas sujeticidades, y por ende sólo objetiviza como instrumentos de mercado, parte del proceso de producción, el de consumo, por lo tanto al no tener los medios económicos que marcan las reglas de juego no puede ser participe y pasa a ser inecesario por la propia ley del mercado, de este modo se convierte en un Dios que justifica los sacrificios en pos de alcanzar su propio y único horizonte. Ante esto, la liberación y la conversión de sujetos acontece cuando la persona tiene el argumento en la resistencia:

El ser sujeto no se manifiesta en lo cotidiano, cuando vivimos nuestros papeles sociales como padres, maridos o esposas, profesores o consumidores. El ser sujeto se manifiesta en la resistencia a las formas concretas de dominación, cuando el individuo resiste a ser reducido a un mero papel social o a un conjunto de papeles. ${ }^{55}$

Y para que esto llegue a suceder, es necesario que:

[...] la persona precisa negar las racionalizaciones legitimadoras producidas por las instituciones. Racionalización que es irracional, pues reduce el sujeto a un objeto. Por eso, algunos autores, como Hinkelammert, piensan ahora el concepto de liberación no apenas como la anticipación del Reino de Dios mediante la edificación de sociedades más justas y humanas, sino también como la recuperación del ser humano como sujeto. ${ }^{56}$

Ahora bien, ¿dónde queda el 'cara a cara' del cual hablamos? lo cual ayudará en el proceso de liberación social y de enfrentamiento ante las lógica totalitarias que niegan la calidad del ser-objeto a ser-sujeto, esto ocurre:

Cuando el individuo se manifiesta y se experimenta como sujeto en la resistencia a las relaciones opresivas, él se puede reconocer como sujeto y, simultáneamente, reconocer el ser sujeto de otras personas más allá de todo y cualquier papel social. Es lo que al inicio hablábamos de la experiencia de la gratuidad en la relación cara a cara. Si no podemos hablar del sujeto como sujeto, no construir instituciones donde las personas no sean objetivadas, podemos vivir nuestro ser sujeto en la resistencialucha y en la relación sujeto-sujeto. ${ }^{57}$ 
La organización en movimientos sociales, eclesiásticos, políticos, ecológicos y comunitarios ayuda, puesto que "para vivir nuestro ser sujetos en la resistencia y en la lucha contra las instituciones opresivas, precisamos participar de otra institución, precisamos actuar como actores sociales" ${ }^{2}$, lo que implica la organización para resistir, debido a que:

El único modo de preservar nuestra calidad de sujetos es no aceptar ser reducidos a ningún papel social, por más importante, 'santo' o 'revolucionario' que éste sea; y no sea aceptar la sacralización de ninguna institución o sistema social. Es la necesidad de la critica a la idolatría y del fetichismo. ${ }^{59}$

Y precisamente esta resistencia se da, como lo mencionamos, en los núcleos de base, creando y forjando relaciones desde abajo y horizontales, rompiendo con la lógica vertical-desde arriba. Precisamente donde las religiones pueden funcionar como núcleos catalizadores de resistencia ante las lógicas totalitarias que intentan destruir al ser humano reduciéndolo a objeto de consumo y negarle otras alterativas. Los movimientos eclesiásticos siempre y cuando pregonen la libertad pueden funcionar como esos espacios alternativos, las imágenes de Dios que construyan serán fundamentales si es que se quiere participar en estos procesos.

Lo importante no es la continuidad de la Teología de la Liberación, sino la liberación en nuestras tradiciones religiosas, que nieguen al Dios que exige el sacrificio, y que propongan la gracia por encima de este método que cada día produce pobreza y violencia en nuestros contextos. Hoy los movimientos eclesiásticos pueden funcionar como espacios donde se experimente el poder ser-sujetos resistiendo a la lógica de homogenización de Dios. Reconstruir los símbolos ayudará a entender mejor el papel libertador en las religiones, para esto es menester construir nuevas pistas hermenéuticas al leer cada una de las tradiciones religiosas y buscar mediante el diálogo un camino en pos de la dignificación humana. La fe que nació de la conciencia de Abraham puede ser una de esas pistas, una fe que negó el carácter sacrificial de nuestros sistemas, y que mediante la recuperación y el reconocimiento de la otredad pudo discernir entre el Dios que privilegia los sacrificios y aquel que opta por la vida, que emana de la gracia mutua de los actores sociales convirtiéndolos en sujetos de la historia y de su historia. 


\section{Notas}

1 El presente ensayo fue presentado en la Escuela Nacional de Antropología e Historia (México, D.F.), en un seminario organizado por la Asociación Latinoamericana para el Estudio de las Religiones (ALER), en junio de 2005.

2 Por esa razón, en la economía capitalista, el ataque a la pobreza es muy importantes, pues busca la inserción de los sectores más pobres al consumo, aunque no por razones de carácter moral y ético. No obstante, para el quehacer teológico crítico, los pobres representan un problema que nace de la falta de ética del propio capitalismo, que, si bien busca insertarlos, en su dinámica termina eliminándolos.

3 Mo Sung, Jung, Sujeto y sociedades complejas: para repensar los horizontes utópicos, San José, DEI, 2005, p. 43-44.

4 Ibid., p. 44.

5 Ibid., p. 46

6 Ibid., p. 47.

$7 \quad$ Ídem.

$8 \quad$ Ibid., p. 48.

$9 \quad$ Ibid., p. 48-49.

10 Richard, Pablo, Fuerza ética y espiritual de la teología de la liberación en el contexto actual de la globalización, San José, DEI, 2004, 76.

11 Ídem.

$12 \quad$ Ibid., p. 77.

13 Es necesario enfatizar que no consideramos a Hinkelammert como teólogo, pues aunque algunas de sus interpretaciones del texto bíblico sean precisas, en otras de ellas puede faltar un método riguroso. Pero sí consideramos que trabaja más por el lado de la ética que encuentra en el texto bíblico.

14 Evangelio según San Mateo 6.12. Énfasis mío.

15 Evangelio según San Lucas 11.4. En ambos textos uso la Nueva Versión Internacional por ser más explicita en esto. Énfasis mío.

16 Hinkelammert, Franz J., Cultura de la esperanza y sociedad sin exclusión, San José, DEI, 1995, p. 333.

17 Ídem.

18 Ibid., p. 334.

19 Ibid., p. 335.

$20 \quad$ Ibid., p. 336.

21 Ibid., p. 343.

22 Ídem. 
$24 \quad$ Ídem.

25 Ibid., p. 345.

26 Ibid., p. 346.

27 Ídem.

28 Ibid., p. 347.

29 Cfr. Génesis 22.11-12.

30 Hinkelammert, Franz, Cultura de la esperanza y sociedad sin exclusión, p. 351.

31 Hinkelammert, Franz, El grito del sujeto. Del teatro-mundo del evangelio de Juan al perro-mundo de la globalización, San José, DEI, 1998, p. 39.

32 Ibid., p. 40.

33 Ídem

$34 \quad$ Ídem.

35 Ídem.

36 Tales autores han sido y siguen siendo criticados por sus posturas teológicas radicales, sin embargo creo que su pensamiento es trascendente para entender la nueva teología protestante en el siglo XX. V. Sperna Weiland, J., La nueva teología protestante, Buenos Aires, Ediciones Carlos Lohlé, 1971.

37 Houtart, François, Mercado y religión, San José, DEI, 2001, p. 177. Houtart ha investigado el fenómeno religioso en Europa, América Latina y del Norte, Asia y África. Su experiencia le permite ver en la religión alternativas al mundo deshumanizado. Es, junto con Samin Amir, organizador del Foro Social Mundial, que es una evento paralelo al Foro Económico Mundial, pero con la finalidad de construir alternativas ante un mundo neoliberal y globalizado.

Ibid., p. 178.

Ídem.

40 No olvidemos todas las dictaduras militares y la respuesta a esto, es decir los procesos de liberación en América Latina. En estos movimientos, la militancia de actores religiosos fue importante.

41 En el caso de El Salvador, no podemos omitir la importancia de Monseñor Romero asesinado el 24 de marzo de 1980. Su memoria ha unido en un espíritu ecuménico trabajos pastorales por medio de la Coordinación Ecuménica de la iglesia de los Pobres en el Salvador (CEIPES).

42 Un ejemplo puede ser el Consejo Mundial de Iglesias, que reúne a distintas denominaciones de corte no católico y que ve con buenos ojos posturas en contra de los totalitarismos.

43 En el caso de México encontramos a la Red Juvenil Interreligiosa, donde se empieza a trabajar desde una propuesta interreligiosa en búsqueda de nuevos modos en el quehacer teológico. 
44 Hourtart, François, Op. cit., p. 181-182.

$45 \quad$ Ibid., p. 81.

$46 \quad$ Ibid., p. 183.

47 Ídem.

48 Ibid., p. 183-184.

49 Ibid., 82-83.

50 Ibid., p. 184.

51 V. Mohamed T. Bensaada, "Una aproximación sociohistórica a las teologías islámicas de la liberación” en François Houtart, Religiones: sus conceptos fundamentales, México, Siglo XXI, 2002, pp.90-133.

52 Houtart, François, Mercado y religión, p. 74.

53 Mo Sung, Jung, Op. cit., p. 53-54.

54 Ibid., p. 54.

55 Ídem.

56 Ídem.

57 Ibid., p. 54-55.

58 Ibid., p. 55.

59 Ibid., p. 55. 